\title{
DEVELOPMENT AND FIELD EVALUATION OF A TRACTOR MOUNTED OIL PALM TRUNK INJECTOR
}

\author{
ABDUL RAZAK JELANI*; MOHD IKMAL HAFIZI AZAMAN*; AMINULRASHID MOHAMED*; MUHAMAD \\ FAUZI ISMAIL*; IDRIS ABU SEMAN*; ABD RAHIM SHUIB*; NORMAN KAMARUDIN and KUSHAIRI, A*
}

\begin{abstract}
This article describes the design, development and testing of a trunk injection machine. The machine comprised of an injection apparatus, hydraulic system and 200-litre storage tank mounted on a mini-tractor. Experiments were conducted to test injection effectiveness test, time and motion study (TMS) and field trial. The injection effectiveness test using $0.1 \%$ eosin dye on the healthy palms revealed that the machine was able to spread the dye to more than $60 \%$ coverage on the vertical $(X)$ and horizontal $(Y)$ axes, and up to $65 \mathrm{~cm}$ upwards on the longitudinal axis $(\mathrm{Z})$. Results recommended to have two injections per palm for a better coverage profile. TMS revealed that the machine was able to treat about 37 palms per day with the injection cost of about RM 3.15 per palm. Study on 2088 Ganoderma-infected palms in an estate showed that $95.6 \%$ of the infected palms were still standing after one year treatment with Hexaconazole. The costeffectiveness was calculated at RM 1.02 per palm over five-year of economic life. With the performance and cost of the machine, it is recommended that this machine is suitable to be used to treat palms infected with basal stem rot disease (BSR).
\end{abstract}

Keywords: trunk injection, trunk injection apparatus, trunk injector, Ganoderma.

Date received: 6 January 2017; Sent for revision: 9 January 2017; Received in final form: 21 August 2017; Accepted: 15 September 2017.

\section{INTRODUCTION}

Oil palm remains the major business to Malaysia which contributes the gross income of about RM 66 billion a year. To sustain a good yield throughout the economic life of oil palm, oil palm growers should implement good agricultural practices (GAP) such as planting the best material, good fertiliser programme, proper field upkeep and efficient harvesting and transportation of fresh fruit bunch (FFB) from the palms until the processing

\footnotetext{
Malaysian Palm Oil Board

6 Persiaran Institusi, Bandar Baru Bangi,

43000 Kajang,

Selangor, Malaysia.

E-mail: razak@mpob.gov.my
}

mill. However, the FFB production can be seriously affected by the occurrence of pests and diseases. Basal stem rot (BSR) diseases caused by the woodrotting fungus called Ganoderma boninense currently becomes the major threat to the oil palm industry. It was reported that BSR could reduce oil palm yields in most of the production areas of the world. It was identified as a major threat to the oil palm industry in Malaysia, Indonesia, Solomon Islands, Papua New Guinea and many more countries around the world. Poor drainage, flooding, nutritional imbalances and heavy weed growth have all been reported to be associated with increased BSR incidence in oil palms. The disease can infect oil palm at all stages of its growth. Infected immature palms normally die within 6-24 months of the first foliar symptoms, while mature palms may survive two to three 
years or more (Turner and Gillbanks, 2003). BSR disease has caused huge economic losses to oil palm plantations (Roslan and Idris, 2012).

Several practices have been introduced to control this diseases such as surgical, removal of infected palms, soil mounding, fungicide treatment or combination of these methods (Ariffin and Idris, 2002; Lalila Naher et al., 2015; Assis et al., 2016). A pressure-injection apparatus was developed to inject fungicides for controlling BSR disease from spreading to other oil palm tissues. This apparatus was reported to be capable of injecting fungicides quickly and efficiently (Idris et al., 2002). Studies also reported that two types of fungicide i.e. Bromoconazole and Hexaconazole, both in the triazole group were effective in prolonging the productive life of infected palms (Idris et al., 2004).

The trend of BSR incidence in Malaysia has been increasing year by year with the estimated yield losses that can reach up to RM 1.5 billion a year (Arif et al., 2011). From the economic point of view, it is crucial to explore various ways and means to control its expansion to ensure the FFB production especially in the infected areas will not be seriously affected by this disease. A proper programme and measures are therefore necessary to ensure the disease is properly monitored and controlled.

\section{Controlling BSR Disease by Trunk Injection}

Tree injection, also known as trunk or stem injection, is a method of targeting precise application of fungicides, pesticides, plant resistance activators, and fertilisers into the xylem vascular tissue of a tree with the purpose of protecting the tree from pests, diseases or for application of nutrition to correct nutrient deficiencies.

Tree injection is currently the most popular method for control of damaging insects, pathogens, and nematodes in landscape tree care. It has been developed primarily for use on large sized trees and in proximity to urban areas where ground- and airspray applications are impractical due to substantial drift-driven pesticide losses or prohibited due to potential human exposure.

Trunk injection has been proven to be one of the effective methods to inject fungicide into the oil palm stems to control the spread of Ganoderma (Idris et al., 2002; Idris, 2007). The pressure injection apparatus (PIA) was found capable of injecting fungicide (Hexaconazole) to the target sites for controlling BSR effectively (Idris et al., 2002). With this technique, fungicide could be applied precisely to the infected sites, ensuring better delivery of the chemical with minimal wastage. The study have shown that the application of Hexaconazole with PIA had limited the spread of Ganoderma infection within the infected standing palms. Study indicated that at 24 and 36 months, palms treated with fungicide using
PIA showed significantly lower mortality rate and higher number of palms producing fruit bunches. Prolonged study to five years showed that $70 \%$ of diseased palms treated with Hexaconazole were still living and producing fruit bunches but none from untreated palms (Idris, 2007). However, the PIA was a semi-mechanised apparatus where several operations were carried out manually.

An improved version using the same principle as PIA was developed (Abdul Razak et al., 2004). The drilling and injecting operations were fully mechanised using a petrol engine. The process included drilling the palm trunk prior to screwing in the injecting nozzle into the drilled hole to apply the fungicide into the palm's stems. The fungicide solution from the storage tank was channelled to the injecting nozzle via a $50 \mathrm{~m}$ length hose. All the machine's components were attached on a minitractor (27 hp hydrostatic mini-tractor). Performance tests conducted showed that the machine took about $3 \mathrm{~min}$ to complete drilling and injection operations per palm. However, several problems were encountered such as liquid leaking along the hose line as well as difficulty to carry the hose along the harvesting path had eventually limited its performance.

However, feedback from the workers who have tested the machine preferred that the machine be operated by only one worker who can control the deployment of the drill and injector from the driver's seat. This enables the machine to be more efficient and user-friendly.

\section{OBJECTIVE}

The objective of the project was to design and develop a trunk injecting machine with the following characteristics: (i) the drill and injector would be mounted on one machine (prime mover), and (ii) the deployment of the moving parts including the drill and injector would be controlled from the driver's seat. The machine would be used to inject fungicides into the palm stems to control the spread of the BSR disease. The effectiveness and performance of the machine would be studied.

This article presents the design and development of a tractor mounted trunk injecting machine and the results of the injection effectiveness, performance tests and the field trial. Some economic analysis will also be discussed besides recommendations to the industry.

\section{MATERIALS AND METHODS}

\section{Design Consideration}

The machine would be operated by one worker with mechanised drilling and injection operations. 
It should be effective and efficient to carry out oil palm trunk injection. There should be no leakage on the hose during high pressure injection $(20$ bar) to avoid wastage. The machine should be easy to handle and able to increase worker's productivity and should be cost-effective.

\section{Design Concept}

The machine comprises five main components i.e. prime mover, injection apparatus, liquid tank, hydraulic control and volume meter. Figure 1 shows the schematic drawing of the prototype which illustrates the components details. All the components i.e. drill, injecting nozzle and hydraulic system are placed on a table mounted on the mini-tractor. The table is fixed at the front of the tractor.

\section{Drill Design}

The drill bit is used to dig holes on the palm trunk for the injector to be pushed in for injection. It was designed to have a threaded part from the middle towards its tip while the remaining section remained a round bar. Its length and diameter were $450 \mathrm{~mm}$ and $11 \mathrm{~mm}$, respectively with the thread's length alone of $220 \mathrm{~mm}$. It was made of high-carbon steel material for heavy duty work.

\section{Injecting Nozzle Design}

The injecting nozzle is the most critical component as it has to withstand huge load which could cause the nozzle to bend or break when it is pushed into the dug hole. It was made of stainless steel i.e. an anti-corrosion material. The length and diameters were $390 \mathrm{~mm}$ and $12 \mathrm{~mm}$, respectively. The diameter of the injector was designed to be slightly bigger than the drill as to provide a tight seal to prevent the injected chemical from gushing out during the high pressure injection process. A liquid path of $2 \mathrm{~mm}$ diameter was made passing through the nozzle with six $2 \mathrm{~mm}$ diameter injection outlets were made on each side of the injecting nozzle as shown in Figure 2.

Autodesk Inventor Professional computer aided design (CAD) software was used to analyse the design. The analysis included the stress analysis, deformation and factor of safety of the injecting nozzle. The analysis confirmed that the design was safe under the design axial load of $16000 \mathrm{~N}$ i.e. estimated force that to be exerted when the injecting nozzle is pushed (by the hydraulic cylinder) into the dug hole on the palm trunk.

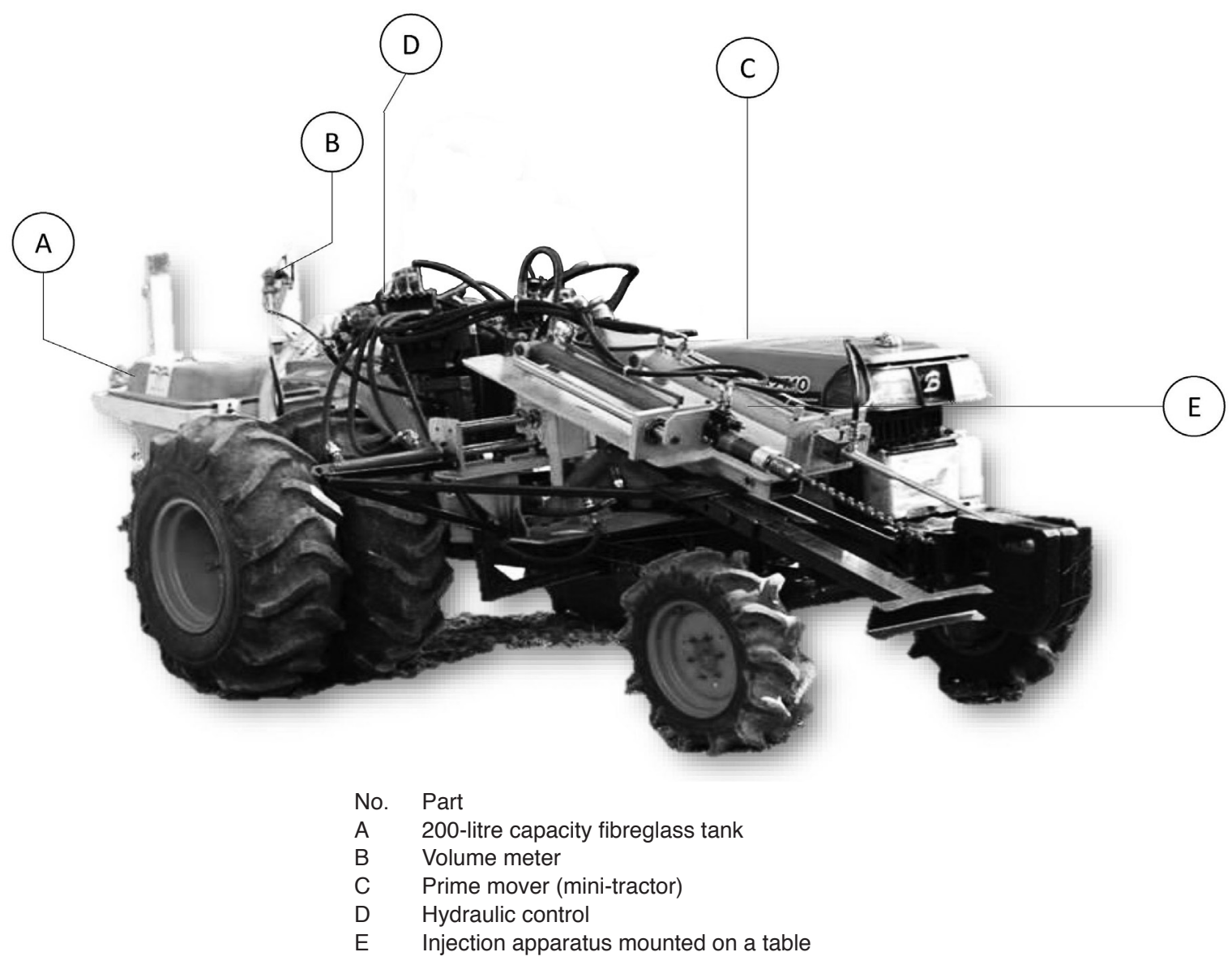

Figure 1. Schematic drawing of the machine. 


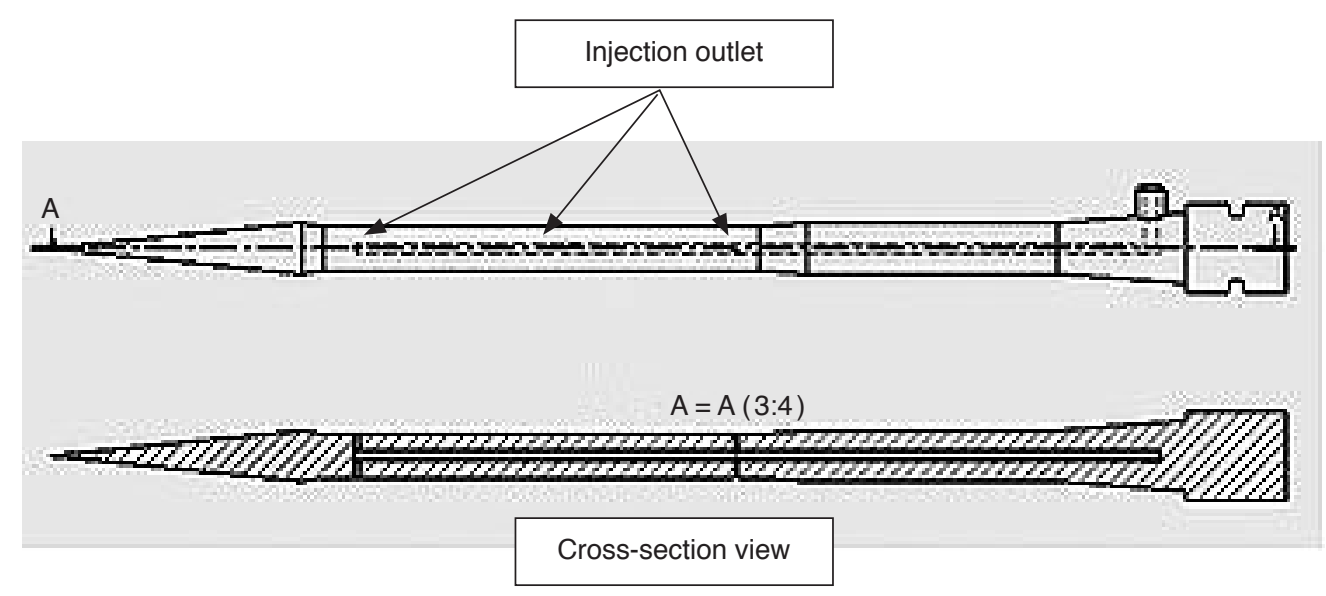

Figure 2. Injecting nozzle.

\section{The Prototype}

Figure 3 shows the prototype of the trunk injecting machine with an operator controlling the whole operations from the driver's seat while Figure 4 shows the drill and the injecting nozzle mounted on the table. Both the stem drilling and the chemical injecting operations were controlled by the operator from the driver's seat. The fungicide solution stored in the tank (placed at the back of the tractor) would be pumped out and channelled via hose into the injecting nozzle. The pressure gauge and volume meter were used to control the injection pressure and the amount of chemical released through the injector. Table 1 shows the specifications of the machine.

\section{Testing}

Three type of tests were conducted to evaluate the effectiveness and performance of the machine, viz. the injection effectiveness test, performance test and the field trial.

\section{Test Location/Trial Site}

Tests were carried out at Felcra Paloh in Kluang, Johor, Malaysia starting in August 2015. All the tests were carried out on 16-year old palms with the average fresh fruit bunch (FFB) production of about $18 \mathrm{t} \mathrm{ha}^{-1} \mathrm{yr}^{-1}$.

\section{Injection Effectiveness Test}

The injection effectiveness test was to study the effectiveness of the machine to spread eosin dye solution in the oil palm's stem. The experiment was conducted using the test procedure that was established by Idris et al. (2002). In the experiment, $0.1 \%$ eosin dye solution (red colour) was injected into the healthy oil palm trunk with a specific volume and pressure to establish a dye distribution profile in the stem. The injection pressure was set at approximately 20 bars to ensure optimum injection and that the dye solution did not gush out from the drilled hole when the pressure was applied. The number of injection was one hole per palm.

TABLE 1. SPECIFICATIONS OF PRIME MOVER, DRILL AND INJECTOR

\begin{tabular}{ll}
\hline Specification of the tractor & \\
Model & Compact Utility Tractor Kubota B2710 \\
Engine & Kubota 1.3L 4-cyl diesel, 27 hp \\
Weight & $789 \mathrm{~kg}$ \\
Wheelbase & $166 \mathrm{~cm}$ \\
Front tyre & $7-12$ \\
Rear tyre & $12.4-16$ \\
\hline Specification of the drill and injecting nozzle & \\
Drill diameter & $11 \mathrm{~mm}$ \\
Drill length & $240 \mathrm{~mm}$ \\
Injector diameter & $12 \mathrm{~mm}$ \\
Total injector length & $372.25 \mathrm{~mm}$ \\
\end{tabular}




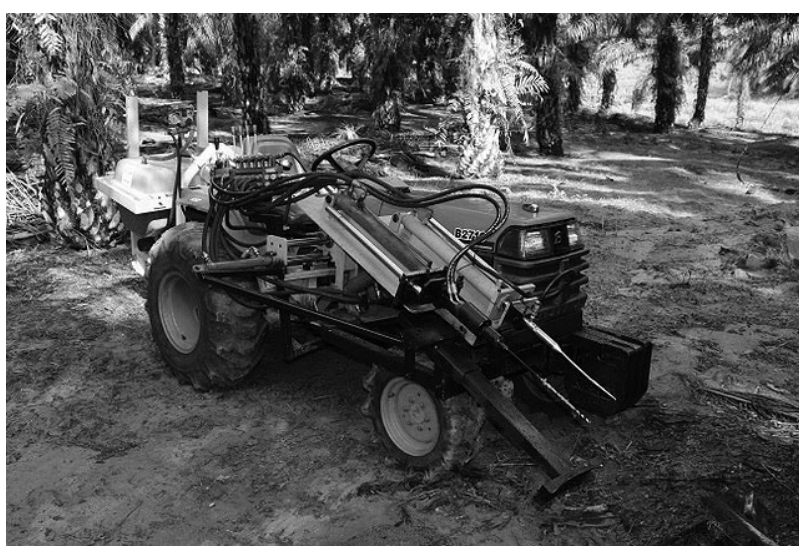

Figure 3. The prototype of tractor mounted trunk injector.

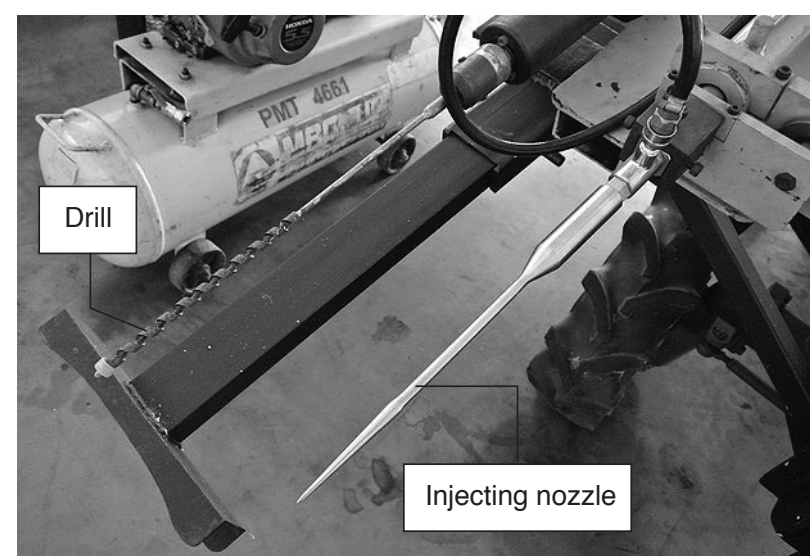

Figure 4. Injecting nozzle and drill mounted on the table.
Three treatments of different volumes were evaluated, viz. 3, 4, and 5 litres of dye solution on three different palms. About half an hour after injection, the palms were felled and cut into two sections, i.e. along longitudinal and cross-sectional axes. The distribution profile of the dye in the palm trunk on each axes was then measured i.e. the vertical and horizontal movements.

\section{Performance Test}

Performance test was to investigate the performance and fuel consumption (diesel) of the machine to treat a given number of infected palms. In this exercise, a total of 258 palms were treated with two injections per palm. Water was used in this exercise. Total days, total hours, amount of fungicide and diesel used and the number of palms treated were counted and recorded.

\section{Field Trial}

Hexaconazole was used in this study. The recommended dilution rate given by Pathology Group of MPOB was $4.4 \mathrm{~g}$ Hexaconazole diluted into 7 litres water or equivalent to $2571 \mathrm{ml}$ of Hexaconazole diluted with water in the 200 litres storage tank. The recommended amount of Hexaconazole to be injected was $90 \mathrm{ml}$ per palm. Two injections per palm were made with 3 litres fungicide solution per hole and 1 litre was sprayed on the ground around the infected palm. In this exercise, only infected palms were treated with the fungicide, considering the expensive price of Hexaconazole (RM 98 per litre during the trial).

The total numbers of palms in Felcra Paloh Estate were 11160 in a 76 ha area, with 2088 palms $(18.71 \%)$ infected with BSR. The topography of the plot where the trial was carried out was undulating. This machine was used to treat 2088 infected palms. The trial commenced in August 2015.

\section{Operation Process}

The operation process of the machine in the field is shown in Figure 5. The operator drives to the marked palms to position the drill bit to the point to be drilled. Once everything is in order, the operator starts drilling a hole and subsequently the injector is then pushed into the hole. The fungicide (Hexaconazole) which is stored in the tank is then released through the injector into the palm tissues. The pressure and the amount of fungicide injected are controlled using the pressure gauge and volume meter. Figure 6 shows the machine at work. In this exercise, the working pressure was set at 20 bars.

\section{RESULTS AND DISCUSSION}

\section{Injection Effectiveness Test}

Figure 7 shows the distribution profile in the oil palm stem after injected with $0.1 \%$ eosin dye solution. Measurements from the point of injection showed that the distances of dye mark on horizontal movement (X) for 3, 4 and 5 litres volume were 40 , 30 and $30 \mathrm{~cm}$, respectively, and for the cross-section axis $(\mathrm{Y})$ were 42,44 and $44 \mathrm{~cm}$ for 3, 4 and 5 litres injection volume, respectively. The results showed that the injection effectiveness was about $47 \%$ to $62 \%$ of coverage for $\mathrm{X}$-axis and $66 \%$ to $69 \%$ of coverage for Y-axis. While for longitudinal axis, the dye mark could go as far as $65 \mathrm{~cm}$ upward for 5 litres injection. The longer distance of $\mathrm{Z}$-axis might be due to capillary action in the stem. Therefore, to increase the coverage distribution, it was recommended that two injections be made per palm in the actual treatment. Table 2 shows the results summary of the injection effectiveness test. As for comparison, the eosin dye distribution profile for PIA were 40.5, 40.0 and $40.6 \mathrm{~cm}$ for $X, Y$ and $Z$ axes, respectively (Idris et al., 2002). Therefore the profiles were about similar between the two apparatuses. 

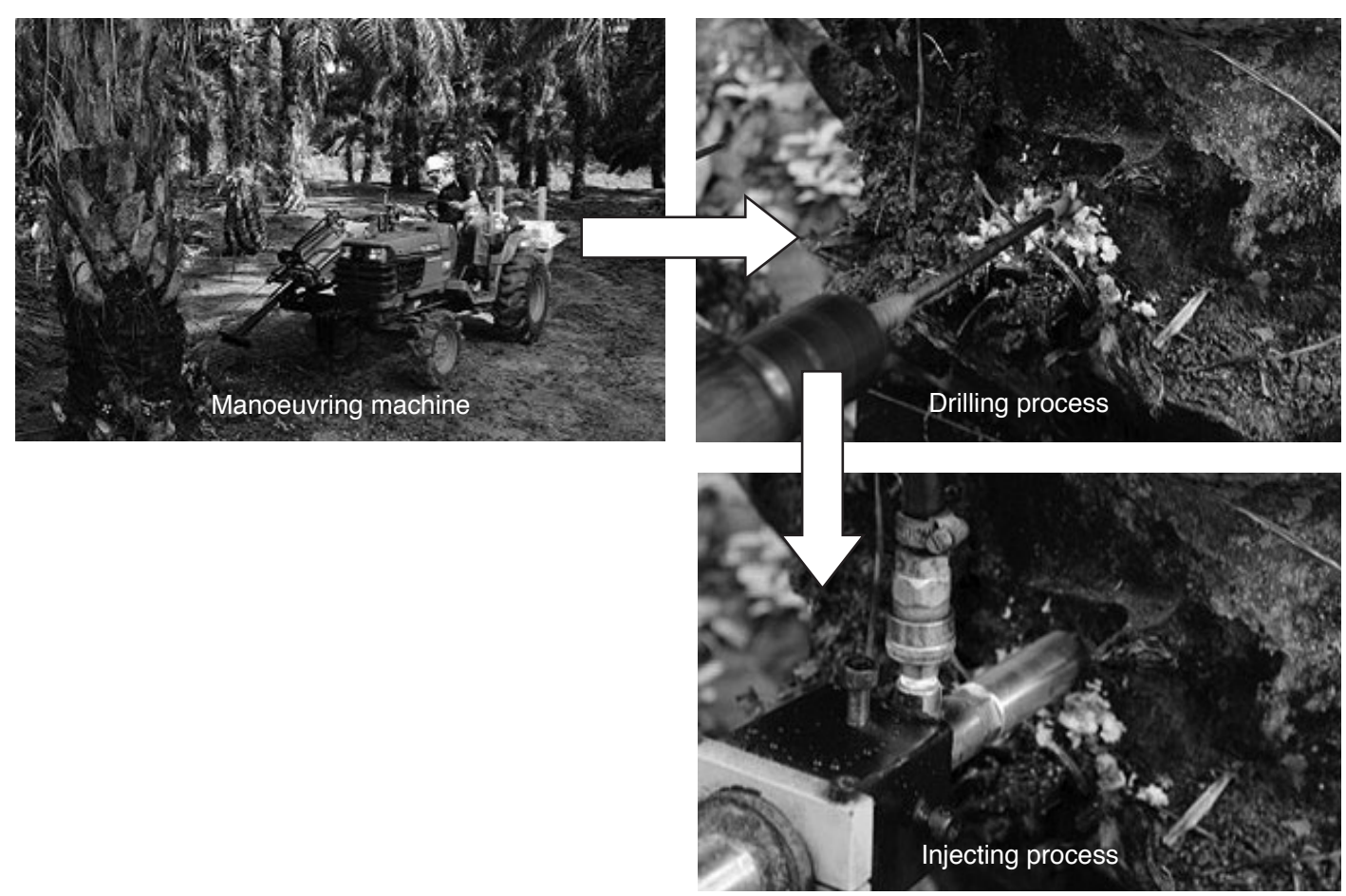

Figure 5. Operation process.

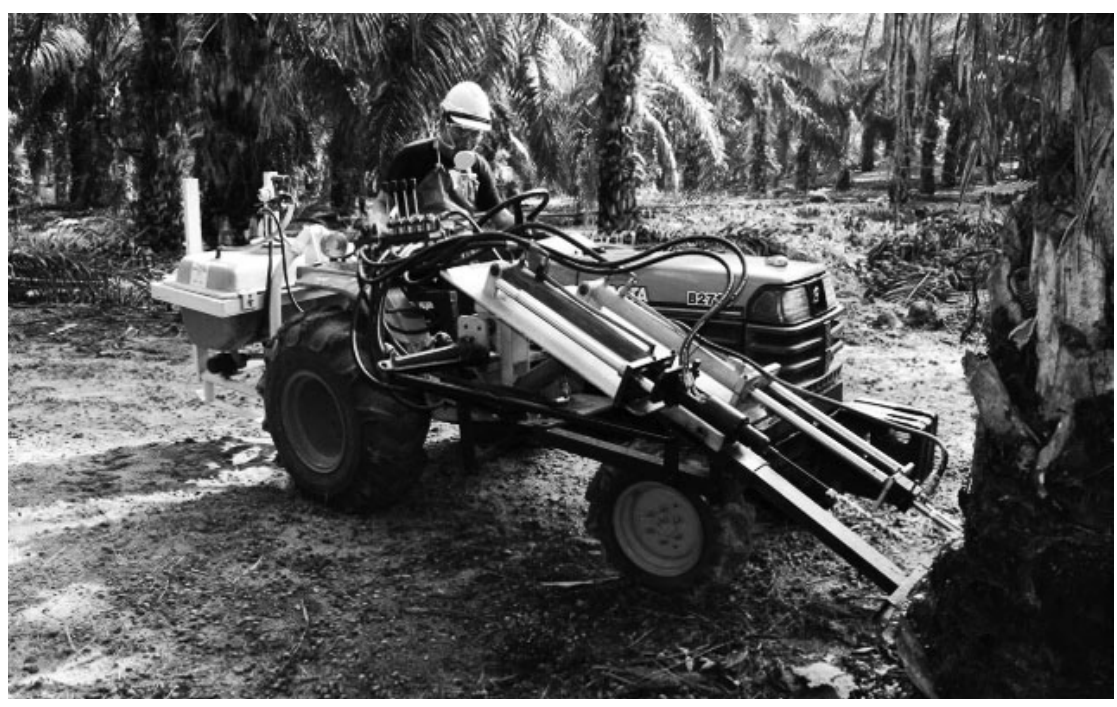

Figure 6. The machine in operation.
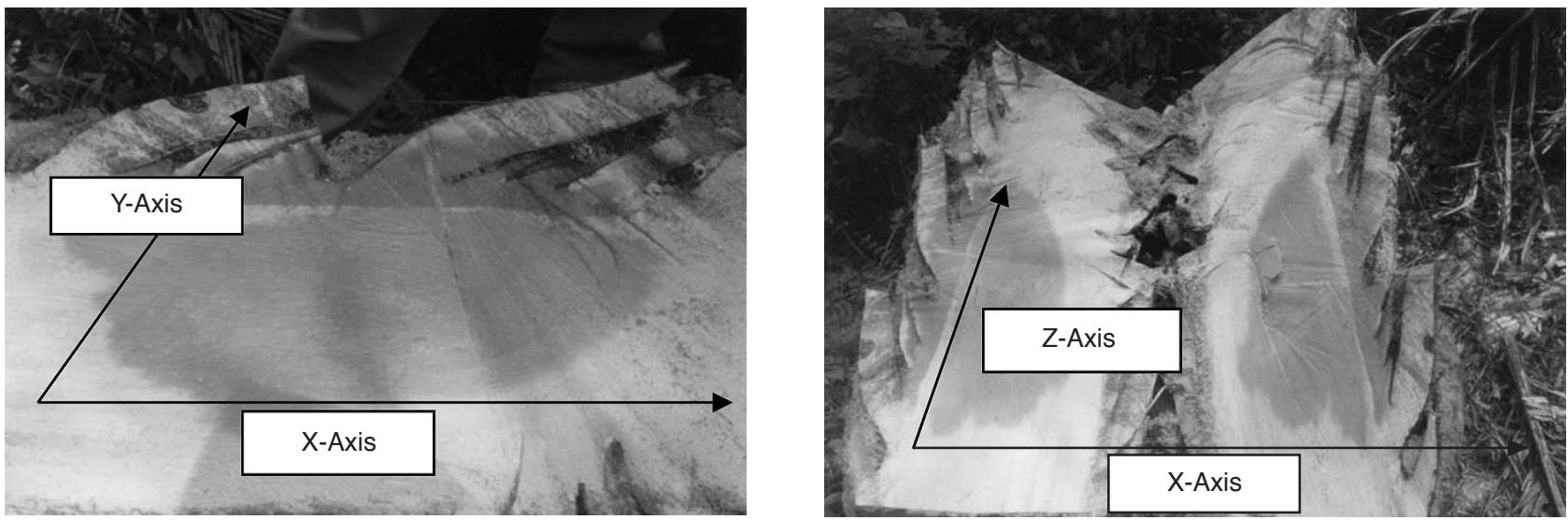

Figure 7. Dye distribution profile on cross-section axis (left) longitudinal axis (right). 
TABLE 2. RESULTS OF INJECTION EFFECTIVENESS TEST

\begin{tabular}{|c|c|c|c|c|c|c|}
\hline & \multicolumn{6}{|c|}{ Injection volume } \\
\hline & \multicolumn{2}{|c|}{ 3-litre } & \multicolumn{2}{|c|}{ 4-litre } & \multicolumn{2}{|c|}{ 5-litre } \\
\hline Axis & Distance $(\mathrm{cm})$ & $\%$ coverage & Distance $(\mathrm{cm})$ & $\%$ coverage & Distance $(\mathrm{cm})$ & $\%$ coverage \\
\hline Z (longitudinal) & 42 & - & 54 & - & 65 & - \\
\hline
\end{tabular}

TABLE 3. PERFORMANCE TEST OF TRACTOR MOUNTED TRUNK INJECTOR

\begin{tabular}{ccccc}
\hline $\begin{array}{c}\text { Total day } \\
\text { (day) }\end{array}$ & $\begin{array}{c}\text { Total hour } \\
\text { (hr) }\end{array}$ & $\begin{array}{c}\text { Total palm treated } \\
\text { (palm) }\end{array}$ & $\begin{array}{c}\text { Total fungicide used } \\
\text { (litre) }\end{array}$ & $\begin{array}{c}\text { Total diesel used } \\
(\text { litre) }\end{array}$ \\
\hline 7 & 31 & 258 & 31 & 30 \\
\hline
\end{tabular}

\section{Performance Test}

Table 3 shows the result of performance test where the machine was used for seven days to treat 258 palms. The results showed that the machine was able to treat about 8.32 palms hr-1 or 37 palms a day with the fuel consumption (diesel) of 0.97 litre $\mathrm{hr}^{-1}$. The performance of this prototype was therefore more than $100 \%$ faster than the PIA (performance of PIA was 15 to 20 min palm ${ }^{-1}$ or about 3 to 4 palms $\left.h r^{-1}\right)$.

\section{Field Trial}

The results of field trial at Felcra Paloh after one year treatment are as follow:

Year planted : 2000

Palms' age : 16 years

Total palms : 11160 palms (76 ha)

Total palm infected with BSR : 2088 palms (18.71\%)

Total palm treated by the machine $: 2088$ palms

Number of palm still standing : 1997 palms (95.64\%)

The result indicated that $95.64 \%$ palms were still standing after one year of treatment with Hexaconazole. The census will go on until five years to see the effect of the treatment. This result was in line with earlier study using PIA. The study showed that $70 \%$ of Ganoderma-infected palms treated with Hexaconazole were still living and producing fruit bunches after five years of treatment but none from untreated palms (Idris, 2007).

\section{ECONOMIC ANALYSIS}

\section{Cost-effectiveness}

Cost-effectiveness is measured in terms of the total palm treated for the period of its economic life against the price of the machine (Stanners, 1992) as in the following equation:

$$
\text { Cost-effectiveness, Ec }=\frac{\text { Machine price }(\mathrm{RM})}{\begin{array}{l}
\text { Total palm treated } \\
(\text { palms })
\end{array}}
$$

\section{Cost-effectiveness of the Prototype (tractor mounted} trunk injector)

$$
\begin{aligned}
& \text { The following assumptions were made: } \\
& \text { Machine price, } \mathrm{M} \quad \text { : RM } 56500 \\
& \text { Economic life, } \mathrm{E} \quad: 5 \text { years } \\
& \text { Productivity, } \mathrm{P} \quad \text { : } 37 \text { palms per day } \\
& \text { Working days per year : } 300 \text { days } \\
& \begin{aligned}
\text { Cost-effectiveness }= & \text { RM } 56500 /(37 \text { palms per } \\
& \text { day } \times 300 \text { days per year } \\
& \text { x } 5 \text { years }) \\
= & \text { RM } 1.02 \text { per palm. }
\end{aligned}
\end{aligned}
$$

Therefore the cost-effectiveness of the machine is about RM 1.02 per palm over five years of economic life of the machine.

\section{Injection Cost per Palm}

For the economic analysis, the fixed costs were the mini-tractor and injector set (Table 4) while variable costs were labour, fuel and lubrication; and repair and maintenance. The operational cost per palm was calculated using a straight-line depreciation method. The details of the calculation are shown in Table 5.

Table 5 shows that the operational cost (excluding chemical cost) was RM 3.15 per palm. The cost is based on the use of mini-tractor as the prime mover. However, the cost can further be reduced if a smaller prime mover is used such as three-wheeler transporters like Badang and Tough Far, where the price of these machines is in the range of RM 15000 to RM 20000 per unit. 
TABLE 4. TOTAL CAPITAL COST OF THE EQUIPMENT

(including mini-tractor)

\begin{tabular}{llr}
\hline No. & Description & Cost (RM) \\
\hline 1 & Injecting nozzle & 300 \\
2 & Drill & 200 \\
3 & Hydraulic system & 3000 \\
4 & Hydraulic table & 1000 \\
5 & Fibreglass tank & 2000 \\
\hline & Total & 6500 \\
\hline \multirow{2}{*}{6} & Mini-tractor & 50000 \\
& Grand total & 56500 \\
\hline
\end{tabular}

TABLE 5. COST ANALYSIS OF EQUIPMENT INCLUDING MINI-TRACTOR USING STRAIGHT LINE DEPRECIATION

\begin{tabular}{llr}
\hline Description & Calculation & Cost (RM per day) \\
\hline Depreciation [(price/ (life span x 12 months x 23 days)] & 56 500/(5 yr x 300 day) & 37.70 \\
Fuel (diesel) @ 4-litre per day & $4 \times$ RM 2/litre & 8.00 \\
Repair \& maintenance cost @ 10\% per year of purchase price & $10 \%$ x 56 500/(300 days per year) & 18.83 \\
Lubrication cost @ 10\% of R\&M & $10 \%$ x 18.83 & 1.88 \\
Labour cost & & 50.00 \\
\hline Total & & 116.41 \\
\hline Cost per palm = total cost/productivity per year & RM 116.41 per day/37 palms per day & 3.15 \\
\hline
\end{tabular}

As for the cost of fungicide (Hexaconazole), it was calculated that the cost per palm was about RM 8.75 as shown by the following calculation:

$$
\begin{aligned}
& \text { Amount of injection per palm } \quad: \quad 7 \text { litres } \\
& \text { Storage tank size } \quad: 200 \text { litres } \\
& \text { Thus, } 1 \text { tank to cover } 28 \text { palms. } \\
& \text { 200 litres requires } 2.5 \text { litres Hexaconazole } \\
& \text { = } 2.5 \text { litres } x \text { RM } 98 / \text { litre }=\text { RM } 245 \\
& \text { Cost of Hexaconazole per palm } \\
& =\text { RM } 245 / 28 \text { palms = RM } 8.75 \text { per palm }
\end{aligned}
$$

Therefore the total operational cost (machine cost plus fungicide cost)

$=$ RM $3.15+$ RM $8.75=$ RM 11.90 per palm.

\section{Sensitivity Analysis of Crop Recovery}

A sensitivity analysis was made to analyse the cost-benefit of trunk injection in relation to different FFB production and prices. Injection frequency is eight times per five year. The FFB productions were varied at 10, 15, 20 and $25 \mathrm{t} \mathrm{ha}^{-1} \mathrm{yr}^{-1}$, while the FFB prices were varied at RM 250, RM 300, RM 350 and RM 400 per tonne. The sensitivity analysis is shown in Figure 8.

The sensitivity analysis would predict the income generated (crop recovery) from each palm (still standing after fungicide treatment) against the cost of trunk injection (machine plus fungicide costs). It can be seen that the profit margin for five years range from RM 20.40 (FFB production at $10 \mathrm{t}$ $\mathrm{ha}^{-1} \mathrm{yr}^{-1}$ and FFB price at RM $\left.300 \mathrm{t}^{-1}\right)$ to RM 289.60 per palm (FFB production at $25 \mathrm{tha}^{-1} \mathrm{yr}^{-1}$ and FFB price at $\mathrm{RM} 400 \mathrm{t}^{-1}$ ) by prolonging the economic life of the palm to five years with Hexaconazole treatment. In other words, controlling BSR with Hexaconazole via trunk injection is still profitable even during low FFB production and low price of FFB.

\section{CONCLUSION}

The project has met its objective where a one-man operation trunk injecting machine was successfully designed, developed and tested. The machine was found capable of injecting fungicide into the targeted tissues effectively. Tests using eosin dye solution had demonstrated that this machine was able to provide a uniform distribution profile in the oil palm stem. The machine was able to treat about 30 to 40 palms a day depending on field topography and the distances of the infected palms. A field trial conducted at Felcra Paloh in Kluang on 2088 Ganoderma-infected palms using Hexaconazole showed that $95.64 \%$ of the infected-palms were still standing and producing bunches after one year of treatment.

Labour requirement was very minimal as it only requires one worker to operate the machine. The operational cost was quite reasonable i.e. RM 3.15 per palm (without fungicide) and RM 11.90 per 


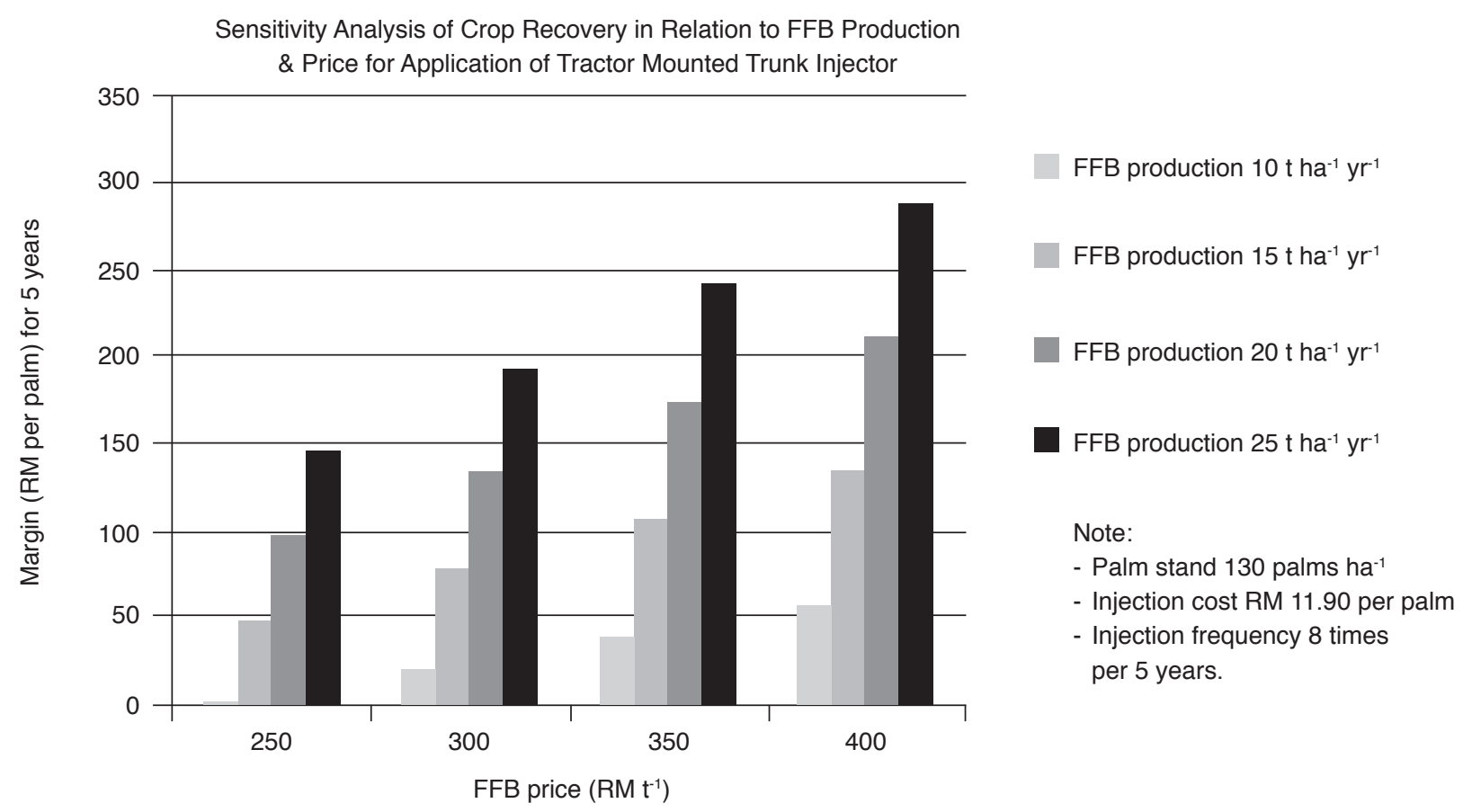

Figure 8. Sensitivity analysis of crop recovery in relation to fresh fruit bunch (FFB) production and price for application of tractor mounted trunk injector.

palm (with fungicide) with the cost-effectiveness of about RM 1.02 per palm for the expected economic life span of five years.

Sensitivity analysis carried out showed that injecting fungicide (Hexaconazale) using this machine into the infected palms will help the estate to gain as much as RM 4 to RM 58 crop recovery per palm per year depending on the FFB production and price, if the economic life of palms can be prolonged to five years.

Therefore, it is recommended that the industry make use of this newly developed machine as a method to control the spread of BSR disease in oil palm estates via trunk injection with Hexaconazole.

\section{ACKNOWLEDGEMENT}

The authors would like to express their appreciation to the manager of Felcra Paloh and their staff who were directly or indirectly involved in the trial by allowing MPOB to use their facilities and estate plot. Appreciation is extended to the staff of Farm Mechanisation Unit, MPOB who had given their full commitment in making the study a success. Valuable comments from fellow colleagues in improving this article are appreciated.

\section{REFERENCES}

ABDUL RAZAK JELANI; AHMAD HITAM; RAMDHAN KHALID; IDRIS ABU SEMAN; ABD
RAHIM SHUIB; AMINULRASHID MOHAMED and MOHD FAUZI ISMAIL (2004). Mechanical trunk injection for Ganoderma control. $M P O B$ Information Series No. 215.

ARIF, M A; ROSLAN, A; IDRIS, A S and RAMLE, M (2011). Economics of oil palm pests and Ganoderma diseases and yield loses. Proc. of the Third International Seminar Integrated Oil Palm Pests and Management. MPOB, Bangi. p. 83-98.

ARIFFIN, D and IDRIS, A S (2002). Progress and research on Ganoderma basal stem rot of oil palm. Paper presented at the Seminar Recent Progress in the Management of Peat and Ganoderma. 6-7 May 2002. MPOB, Bangi. 50 pp.

ASSIS, K; CHONG, K P; IDRIS, A S and HO, C M (2016). Economic loss due to Ganoderma in oil palm. International J. Social, Behavioural, Educational, Economic, Business and Industrial Engineering Vol. 10 No 2.

IDRIS, A S; ISMAIL, S; ARIFFIN, D and AHMAD, $\mathrm{H}$ (2002). Control of Ganoderma infected palm - development of pressure injection and field applications. MPOB Information Series. No. 131.

IDRIS, A S; ISMAIL, S; ARIFFIN, D and AHMAD, $\mathrm{H}$ (2004). Prolonging the productive life of infected palms with Hexaconazole. MPOB Information Series No. 214. 
IDRIS, A S; ISMAIL, S and ARIFFIN, D (2004). Innovative technique of sanitation for controlling Ganoderma at replanting. MPOB Information Series No. 213.

IDRIS, A S (2007). Managing the Ganoderma basal stem rot in oil palm plantation through sanitation and fungicidal treatment. Proc. of the 2007 Conference on Plantation Commodities: Malaysia Commodity Crops 100 Years. p. 322.

IDRIS, A S; MIOR, M H A Z; MAIZATUL, S M; and KUSHAIRI, A (2011). Survey on status of Ganoderma disease of oil palm in Malaysia 2009- 2010. Proc. of the PIPOC 2011 International Palm Oil Congress Agriculture Conference. MPOB, Bangi. p. 235-238.

LAILA NAHER; SHAFIQUZZAMAN SIDDIQUEE; UMI KALSOM YUSUF and MONDAL, M M A
(2015). Issues of Ganoderma spp. and basal stem rot disease management in oil palm. American J. Agricultural Science Vol. 2(3): 103-107.

ROSLAN, A and IDRIS, A S (2012). Economic impact of Ganoderma incidence on Malaysian oil palm plantation - a case study in Johor. Oil Palm Industry Economic J. Vol. 12 No. 1: 24-30.

STANNERS, G H (1992). Investigating the true cost of conventional harvesting tools. Paper presented at the Eastern Plantation Agency Bhd Seminar. June 1993.

TURNER, P D and GILLBANKS, R A (2003). Oil Palm Cultivation and Management. $2^{\text {nd }}$ ed. The Incorporated Society of Planters, Kuala Lumpur. p. 682-693. 